\begin{tabular}{|c|c|c|c|c|c|}
\hline \multirow{2}{*}{$\begin{array}{l}\text { To } \\
\text { Distribution }\end{array}$} & \multirow{2}{*}{\multicolumn{3}{|c|}{$\begin{array}{l}\text { From } \\
\text { Operations \& Transition } \\
\text { Facilities Projects }\end{array}$}} & \multicolumn{2}{|l|}{ Page 1 of 1} \\
\hline & & & & \multicolumn{2}{|c|}{ Date $12 / 29 / 94$} \\
\hline \multirow{2}{*}{\multicolumn{4}{|c|}{ 03-F031, Sodium Storage Facility. WHC-SD-F031-C }} & \multirow{2}{*}{\multicolumn{2}{|c|}{$\begin{array}{ll}\text { EDT No. } & 604248 \\
\text { ECN No. } & \text { N/A }\end{array}$}} \\
\hline & & & & & \\
\hline Name & MSIN & $\begin{array}{l}\text { Text } \\
\text { With All } \\
\text { Attach. }\end{array}$ & Text Only & $\begin{array}{l}\text { Attach./ } \\
\text { Appendix } \\
\text { Only }\end{array}$ & $\begin{array}{l}\text { EDT/Dist. } \\
\text { Sheet } \\
\text { Only }\end{array}$ \\
\hline $\begin{array}{l}\text { R. A. Almquist } \\
\text { D. J. Carrell } \\
\text { D. M. Collado } \\
\text { W. S. Chin (2 copies) } \\
\text { G. B. Estes } \\
\text { O. A. Farabee } \\
\text { S. Guttenberg } \\
\text { R. K. Hulvey } \\
\text { J. R. Kelly } \\
\text { E. J. Krejci } \\
\text { C. J. McCargar } \\
\text { J. C. Midgett } \\
\text { J. E. Parker } \\
\text { D. L. Polzin } \\
\text { G. L. Rippy } \\
\text { W. S. Roe } \\
\text { L. D. Salsberry } \\
\text { J. W. Schultz } \\
\text { D. R. Shank (2 copies) } \\
\text { N. K. Snyder (3 copies) } \\
\text { L. R. Tollbom } \\
\text { T. L. Watson } \\
\text { Project Files } \\
\text { FFTF TPo Files } \\
\text { Central Files } \\
\text { OSTI (2 copies) }\end{array}$ & $\begin{array}{l}\text { N2-36 } \\
H 6-22 \\
\text { A5-18 } \\
\text { A5-18 } \\
\text { G6-02 } \\
\text { R3-79 } \\
\text { N2-53 } \\
\text { N2-33 } \\
\text { R3-28 } \\
\text { N1-72 } \\
\text { N2-56 } \\
\text { N2-51 } \\
\text { N1-71 } \\
\text { N2-56 } \\
\text { R3-35 } \\
\text { S2-56 } \\
\text { E6-03 } \\
\text { E6-03 } \\
\text { R3-35 } \\
\text { S3-10 } \\
\text { N2-53 } \\
\text { S3-10 } \\
\text { R1-28 } \\
\text { N2-53 } \\
\text { L8-04 } \\
\text { L8-07 }\end{array}$ & $\begin{array}{l}X \\
X \\
X \\
X \\
X \\
x \\
X \\
X \\
X \\
X \\
\\
X \\
X \\
X \\
X \\
\end{array}$ & & & $\begin{array}{l}X \\
X \\
X \\
X\end{array}$ \\
\hline
\end{tabular}




\section{DISCLAIMER}

Portions of this document may be illegible in electronic image products. Images are produced from the best available original document. 


2. To: (Receiving Organization)
Distribution

Distribution

5. Proj./Prog./Dept./Div.:

$03-\mathrm{F}-031$

8. Originator Remarks:

Approve and release the attached Project Quality Assurance PJan for Project F-031.

11. Receiver Remarks:
3. From: (originating Organization)

Operations \& Transition

Facilities Projects

6. Cog. Engr.:

DR Shank
4. Related EDT No.:

N/A

7. Purchase Order No.:

N/A

9. Equip./Component No.:

$N / A$

10. System/Bldg./Facility:

FFTF 491-W, 4717, 403

12. Major Assm. Dwg. No.: N/A

13. Permit/Permit Application No.: $N / A$

14. Required Response Date:

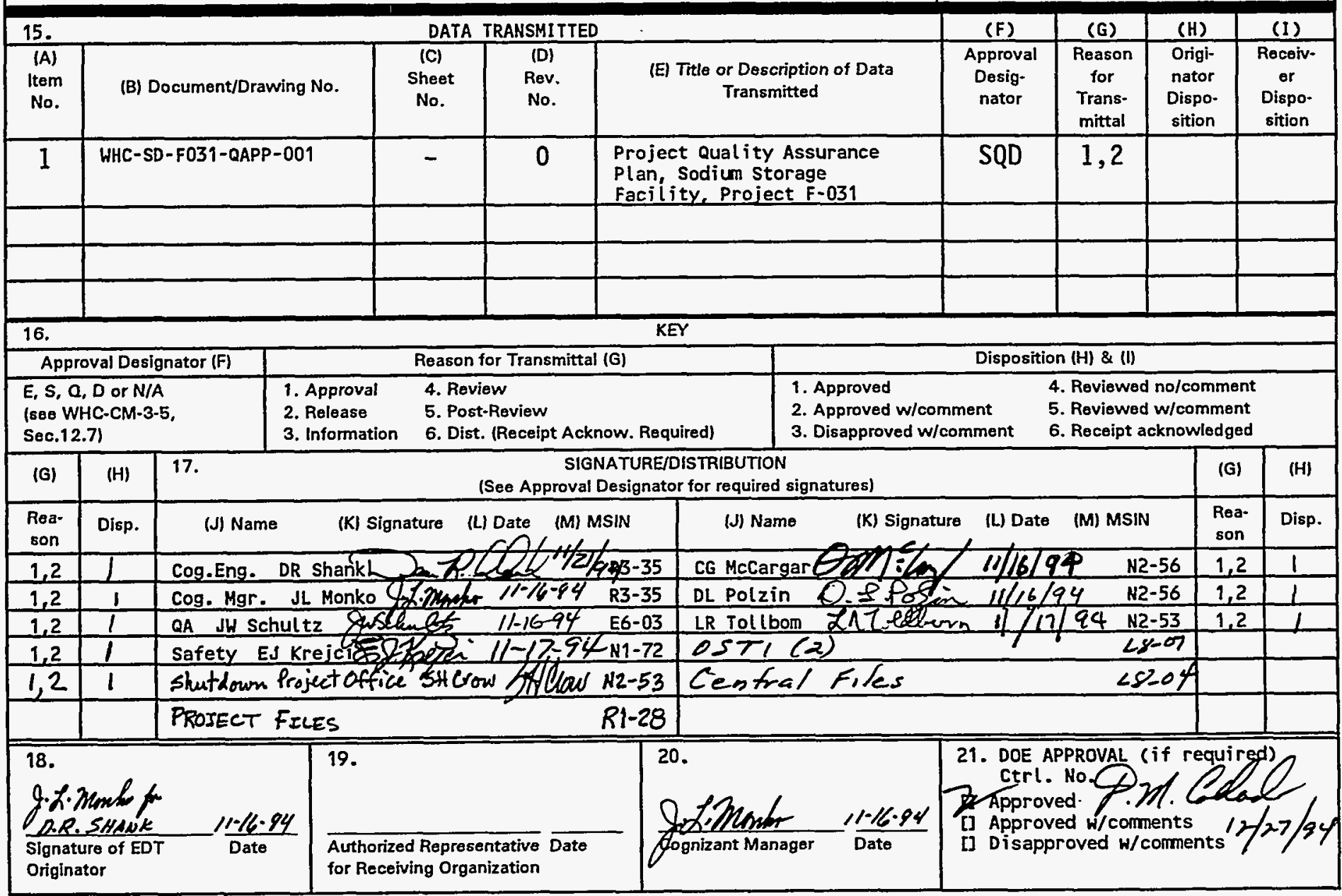




\section{RELEASE AUTHORIZATION}

\begin{tabular}{ll}
\hline Document Number: & WHC-SD-F031-QAPP-001, REV 0 \\
\hline Document Title: & $\begin{array}{l}\text { Project Quality Assurance P1 an, Sodium Storage } \\
\text { Facility, project F-031 }\end{array}$
\end{tabular}

Release Date: $\quad 12 / 29 / 94$

\section{This document was reviewed following the procedures described in WHC-CM-3-4 and is:}

\section{APPROVED FOR PUBLIC RELEASE}

\section{WHC information Release Administration Specialist:}

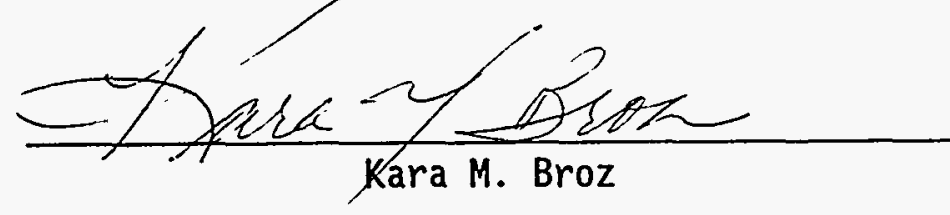

TRADEMARK DISCLAIMER. Reference herein to any specific comercial product, process, or service by trade name, trademark, manufacturer, or otherwise, does not necessarily constitute or imply its endorsement, recommendation, or favoring by the United States Government or any agency thereof or its contractors or subcontractors.

This report has been reproduced from the best available copy. Available in paper copy and microfiche. Printed in the United States of America. Available to the U.S. Department of Energy and its contractors from:

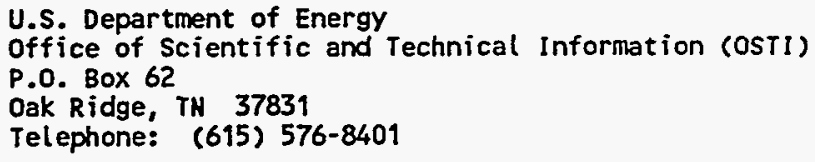

Available to the public from:

U.S. Department of Cormerce

National Technical Information Service (NTIS)

5285 Port Royal Road

Springfield, VA 22161

Telephone: '(703) $487-4650$ 


\begin{tabular}{|c|c|c|}
\hline $\begin{array}{l}\text { 2. Title } \\
\text { Project Quality Assurance Plan, Sodium Storage } \\
\text { Facility, Project F-031 }\end{array}$ & $\begin{array}{l}\text { 3. Number } \\
\text { WHC-SD-F031-QAPP- } \\
001\end{array}$ & $\begin{array}{c}\text { 4. Rev No. } \\
0\end{array}$ \\
\hline $\begin{array}{l}\text { 5. Key words } \\
\text { Project Quality Assurance Plan } \\
\text { Sodium Storage Facility } \\
\text { QAPP } \\
\text { SSF } \\
\text { FFTF KMB } 1 / 29 / 94 \text { PUBLIO }\end{array}$ & $\begin{array}{l}\text { 6. Author } \\
\text { Name: JW Schultz/D }\end{array}$ & $\begin{array}{l}\text { hank } \\
\text { freA SHANK } \\
160 / B 194 P\end{array}$ \\
\hline
\end{tabular}

7. Abstract

The Sodium Storage Facility Project Quality Assurance Plan delineates the quality assurance requirements for construction of a new facility, modifications to the sodium storage tanks, and tie-ins to the FFTF Plant.

\section{DISCLAIMER}

This report was prepared as an account of work sponsored by an agency of the United States Government. Neither the United States Government nor any agency thereof, nor any of their employees, makes any warranty, express or implied, or assumes any legal liability or responsibility for the accuracy, completeness, or usefulness of any information, apparatus, product, or process disclosed, or represents that its use would not infringe privately owned rights. Reference herein to any specific commercial product, process, or service by trade name, trademark, manufacturer, or otherwise does not necessarily constitute or imply its endorsement, recommendation, or favoring by the United States Government or any agency thereof. The views and opinions of authors expressed herein do not necessarily state or reflect those of the United States Government or any agency thereof.

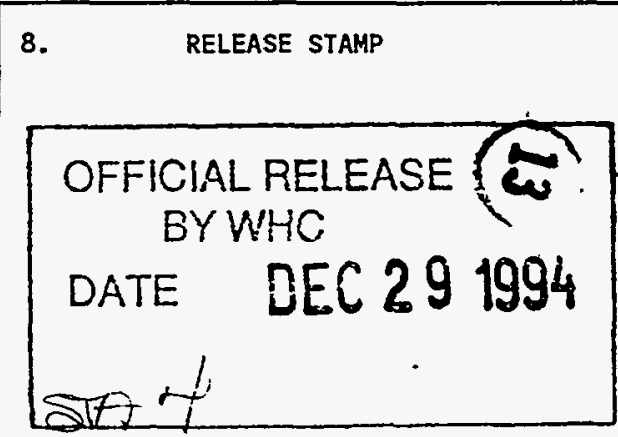




\title{
PROJECT QUALITY ASSURANCE PLAN
}

\author{
SODIUM STORAGE FACILITY \\ PROJECT F-031 \\ Issued by: \\ WESTINGHOUSE HANFORD COMPANY \\ NOVEMBER 1994
}

for the

\section{U.S. DEPARTMENT OF ENERGY \\ RICHLAND OPERATIONS OFFICE \\ RICHLAND, WASHINGTON}

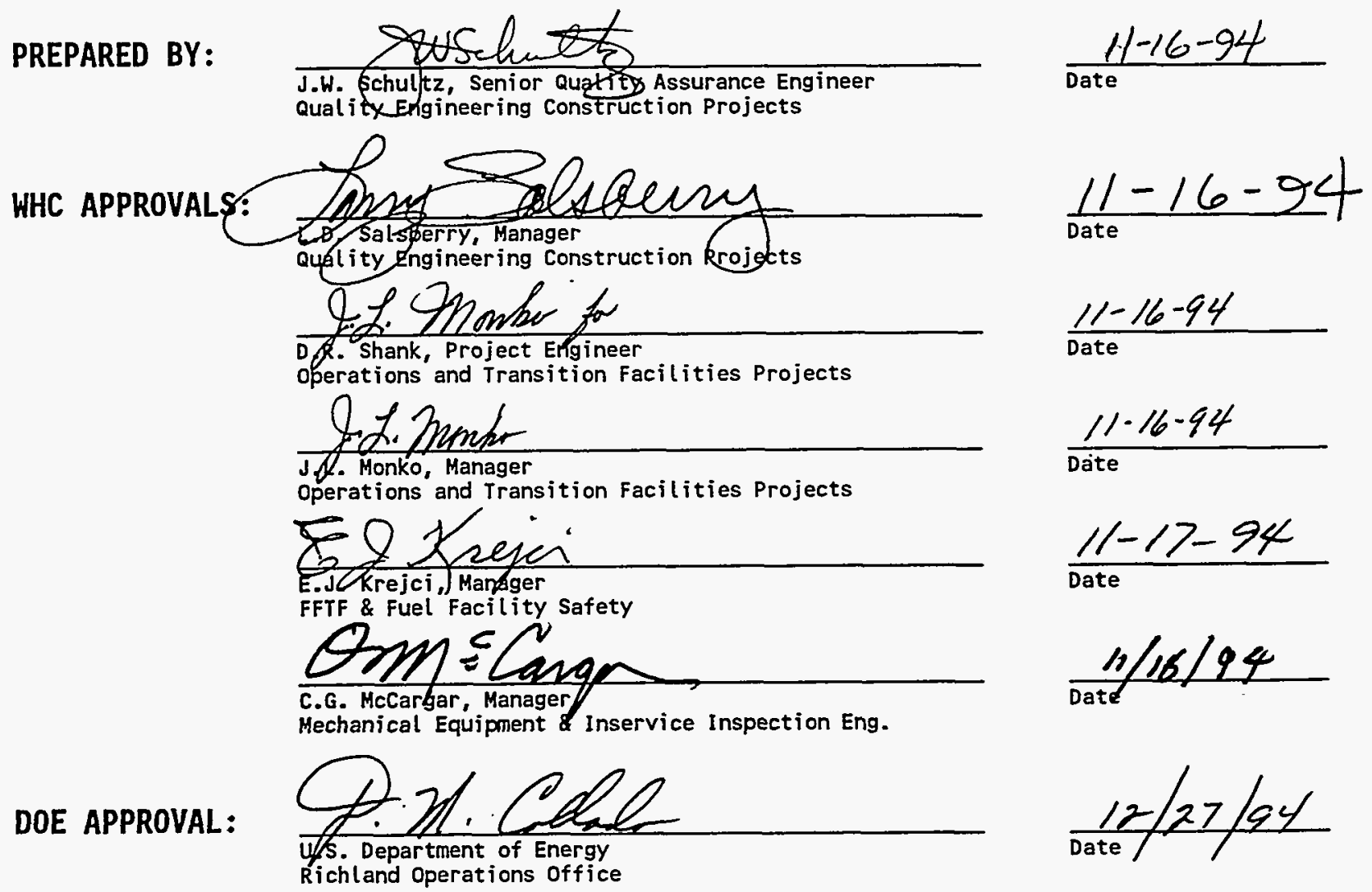


WHC-SD-F031-QAPP-001, Rev. 0

Page 2 of 16

\section{TABLE OF CONTENTS}

Page

1.0 Scope

3

2.0 Responsibilities 3

3.0 Quality Assurance Program Requirements 4

4.0 Quality Index of Implementing Procedures 8

$\mathbf{5 . 0}$ References 9

6.0 Attachments

6.1 Attachment I (QA Requirements for WHC safety classes) 10

6.2 Attachment 2 (Project Critical Characteristics) 11

6.3 Attachment 3 (Description of Types of Inspection) 15

6.4. Attachment 4 (Quality Assurance Program Index) 16 


\subsection{SCOPE}

1.1 This Quality Assurance Plan (QAP) identifies the Westinghouse Hanford Co. (WHC) Quality Assurance (QA) program requirements for all contractors involved in the planning and execution of the design, procurement, construction, testing and inspection of the Sodium Storage Facility, Project F-031. This plan provides direction for the types of verifications necessary to satisfy the functional requirements within the project scope and applicable regulatory requirements determined in the Project Functional Design Criteria (FDC), WHC-SD-FF-FDC-009.

1.2 The extent of this project Quality Assurance Plan will be for activities including the Sodium Storage structure, piping, HVAC, electrical, fire protection, transfer piping to/from FFTF, and the installation and tiein of Sodium Storage tanks in the new facility. All modifications to the tanks will be completed by the Construction Contractor (CC) under the control of the Operating Contractor. Procurement of other components to be identified as Government Furnished Equipment wi11 not be a part of this QAP.

\subsection{RESPONSIBILITIES}

2.I The Department of Energy (DOE) has the responsibility to determine the requirements for assuring quality, and the contractors are responsible for installing and implementing Quality Assurance (QA) in accordance with their contractual requirements, as stated in DOE 4700.1 , Section III, Part D.

2.2 The Operating Contractor (OC) is responsible for the overview of al1 quality related documentation for the project design, procurement, fabrication, and construction. This overview is to ensure conformance with the requirements of the Functional Design Criteria and based upon the $O C$ approved procedures.

2.3 The responsibility for the project design, procurement, fabrication, construction, and acceptance inspection shall be identified within the confines of the Work Breakdown Structure (WBS) located in the Project Management Plan, as prepared by the Project Engineer. If the responsibilities are changed during the course of the project, these changes shall be made per OC approved procedures.

2.4 The Construction Contractor (CC) is responsible and held accountable for all aspects of project quality. The CC shall perform, or have performed, the quality verification activities as specified in the contract and identified in the drawings, specifications and other approved project documents. 


\subsection{QUALITY ASSURANCE PROGRAM REQUIREMENTS}

3.1 The design, procurement, fabrication and construction activities shall conform to the quality assurance/quality control provisions of the codes and standards specified in the approved project documents. Codes and standards shall have the edition, addenda, year, or revision identified in the Definitive Design documents (e.g. Construction Specifications and/or Drawings). These issue dates shall be based upon the start of the Definitive Design process.

3.2 The safety classification shall be determined by analysis in accordance with WHC-CM-4-46, 9.0 and WHC-CM-1-3, MRP 5.46. These procedures shal1 be used as a method in determining the risk involved which shall be applied to items and processes. Currently, there are safety class 2, safety class 3 systems, and non-safety class 4 components, and structures identified in this project. A Preliminary Safety Evaluation (PSE), WHC-SD-FF-PSE-002, has been prepared to document safety analysis information on the project.

3.3 The QA Requirements for WHC safety classes (Attachment 1) of systems, components, and structures is the basis for the requirements of this plan. They shall be used in design and construction as the basis for determining WHC quality assurance program requirements. The Project Functional Design Criteria further imposes DOE Order 5700.6C, "Quality Assurance". The rigor with which the Quality Assurance requirements will be applied shail be based upon the a "graded approach". The identification of the safety class will assist in the application of this "graded approach" to quality.

3.4 The Project Critical Characteristics (Attachment 2) denotes the safety class and types of inspections required for typical systems, components, or structures being designed or constructed within the scope of this project. The Comments section provides minimal references to suggested codes or standards to be used for direction to determine the types of inspections required to be performed. This does not relieve the Designer of the responsibility to ensure applicable requirements have been identified. The systems, components, or structures identified by Safety Classification on the Project Critical Characteristics Sheet are based upon the information supplied within the Preliminary Safety Evaluation, WHC-SD-FF-PSE-002, Appendix B.

3.5 The Description of Types of Inspection (Attachment 3 ) is a detailed description of the types of inspections to be performed during the execution of construction. This description for inspection is reproduced from DOE Order 4700.1 , Chapter V, Part C, Paragraph 3.c. (3)(c).

3.6 Contractors performing work on this project sha11 maintain a management system which addresses the applicable Quality Assurance Programmatic requirements as determined by the Safety Class of the systems affected. 
It shall be the responsibility of each contractor to ensure that their sub-tier contractor complies with the applicable quality requirements as delineated herein.

3.6.1 The Architect-Engineer (A-E) who performs design activities on Safety Class 2 systems, components, or structures shall maintain a management system which addresses Quality Assurance Programmatic requirements of Nationa7 Consensus Standard ASME NQA-1 and DOE Order 5700.6C, "Quality Assurance." The program shall meet the following basic requirements of NQA-1, and the additional criterion identified from DOE Order 5700.6C, as a minimum:

\section{NQA-1 Basic Requirements:}

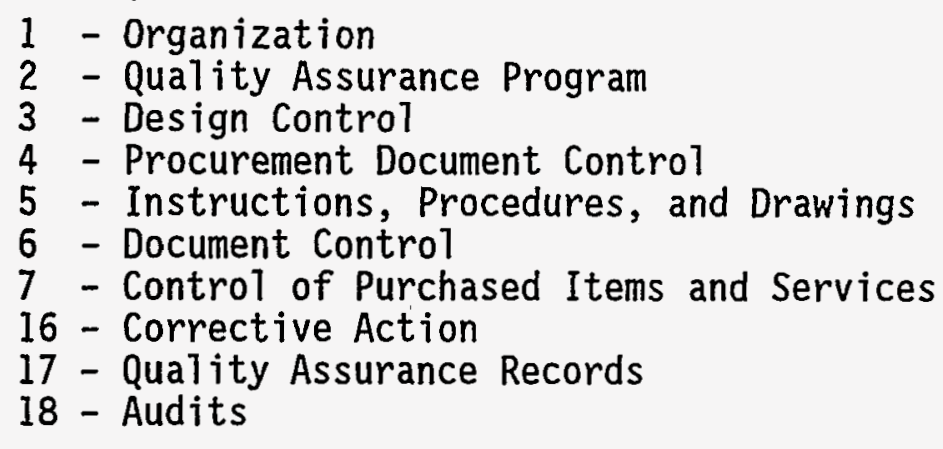

DOE Order 5700.6C Criterion:

3 - Quality Improvement

9 - Management Assessment

3.6.2 The A-E who performs design activities on Safety Class 3 or non-safety class 4 systems, components, or structures shall have a management system in $p 7$ ace. This does not require the A-E to have a formal ASME NQA-1 program, however, the A-E must have procedures and/or instructions which, as a minimum, address the following requirements:

a) ORGANIZATION - The organizational structure, functional responsibilities, levels of authority, and 7 ines of communication for activities affecting quality shal1 be documented.

b) DESIGN CONTROL - Design interfaces shall be identifiable and controlled. Design adequacy shall be verified by persons other than those who designed the item. Design changes, including field changes shall be defined and governed by control measures commensurate with original design.

c) DOCUMENT CONTROL - The preparation, issue, and change of documents that specify quality requirements or prescribe activities affecting quality shall be controlled to assure that correct documents are being employed. 
d) INSTRUCTIONS, PROCEDURES, AND DRAWINGS - Activities affecting quality shall be prescribed by and performed in accordance with documented instructions, specifications, procedures, or drawings of a type appropriate to the circumstances.

e) QUALITY ASSURANCE RECORDS - Records that furnish documentary evidence of quality shall be specified, prepared, and maintained. Records shall be legible, identifiable, and retrievable. Records shail be protected against damage, deterioration, or loss. Requirements and responsibilities for record transmittal, distribution, retention, maintenance, and disposition shall be established and documented.

f) QUALITY IMPROVEMENT - The organization shall establish and implement processes to detect and prevent quality problems and to ensure quality improvement. Items and processes that do not meet established requirements sha11 be identified, controlled, and corrected. Correction sha17 include identifying the causes of problems and preventing recurrence. Item reliability, process implementation, and other quality-related information sha11 be reviewed and the data analyzed to identify items and processes needing improvement.

g) MANAGEMENT ASSESSMENT - Management at al1 levels shall periodically assess the integrated quality assurance program and its performance. Problems that hinder the organization from achieving its objectives shat7 be identified and corrected.

NOTE: For guidance as to what the procedures or instructions should address, ASME NQA-1 Basic Requirements and DOE Order 5700.6C concerning the above requirements should be reviewed.

3.6.3 For procurement, fabrication, construction, and inspection of Safety Class 2 items, the performing organization shall have a management system which addresses Quality Assurance Programmatic requirements of National Consensus Standard ASME NQA-1 and DOE Order 5700.6C, "Quality Assurance." The program shall meet the following basic requirements of NQA-1, and the additional criterion identified from DOE Order 5700.6C, as a minimum:

NQA-1 Basic Requirements:

1 - Organization.

2 - Quality Assurance Program

4 - Procurement Document Control

5 - Instructions, Procedures, and Drawings

6 - Document Control

7 - Control of Purchased Items and Services

8 - Identification and Control of Items

9 - Control of Processes

10 - Inspection

11 - Test Control

12 - Control of Measuring and Test Equipment 
13 - Handling, Storage, and Shipping

14 - Inspection, Test, and Operating Status

15 - Control of Nonconforming Items

16 - Corrective Action

17 - Quality Assurance Records

18 - Audits

DOE Order $5700.6 C$ Criterion:

3 - Quality Improvement

9 - Management Assessment

3.6.4 Those organizations performing procurement, fabrication, construction, and inspection activities. on Safety Class 3 or non-safety class 4 systems, components, and structures shall have a management system in place. This does not require the organization to have a formal quality assurance program, however, they must have procedures and/or instructions which, as a minimum, address the following requirements:

a) PROCUREMENT DOCUMENT CONTROL - AppTicable design bases and other requirements necessary to assure adequate quality shall be included or referenced in documents for procurement of items or services.

b) DOCUMENT CONTROL - The preparation, issue, and change of documents that specify quality requirements or prescribe activities affecting quality shall be controlled to assure that correct documents are being employed.

c) INSPECTION - Inspections shall be planned. Characteristics to be inspected and inspection methods shall be specified. Inspections shall be documented. Inspection for acceptance shall be performed by persons other than those who performed or directly supervised the work being inspected.

d) TEST CONTROL - Tests required to verify conformance or demonstrate performance shall be planned and executed. Test results shall be documented and their conformance with acceptance criteria evaluated.

e) INSTRUCTIONS, PROCEDURES, AND DRAWINGS - Activities affecting quality shall be prescribed by and performed in accordance with documented instructions, procedures, or drawings of a type appropriate to the circumstances.

f) CONTROL OF MEASURING AND TEST EQUIPMENT - Measuring and test equipment used for activities affecting quality shall be controlled and cal ibrated.

g) CONTROL OF NONCONFORMING ITEMS - Controls shal1 provide for identification, documentation, evaluation, segregation when practical, dispositioning of nonconforming items, and for notification to affected organizations. 
h) QUALITY ASSURANCE RECORDS - Records that furnish documentary evidence of quality shall be specified, prepared, and maintained. Records shall be legible, identifiable, and retrievable. Records shall be protected against damage, deterioration, or loss. Requirements and responsibilities for record transmittal, distribution, retention, maintenance, and disposition shall be established and documented.

i) QUALITY IMPROVEMENT - The organization shall establish and implement processes to detect and prevent quality problems and to ensure quality improvement. Items and processes that do not meet established requirements shall be identified, controlled, and corrected. Correction shall include identifying the causes of problems and preventing recurrence. Item reliability, process implementation, and other quality-related information shall be reviewed and the data analyzed to identify items and processes needing improvement.

j) MANAGEMENT ASSESSMENT - Management at all levels shall periodically assess the integrated quality assurance program and its performance. Problems that hinder the organization from achieving its objectives shall be identified and corrected.

NOTE: For guidance as to what the procedures or instructions should address, ASME NQA-1 Basic Requirements and DOE Order 5700.6C concerning the above requirements should be reviewed.

3.6.5 Construction specifications and drawings shall specify specific code required inspection activities to be performed and to identify the responsible contractor(s) which will perform such activities.

\subsection{QUALITY INDEX OF IMPLEMENTING PROCEDURES}

4.1 An Operating Contractor Quality Assurance Program Index (QAPI), Attachment 4, is supplied. The QAPI is a listing in Chart Format of Manuals, which contain general procedures, and some specific procedures to be utilized on the Project. The procedures from the WHC Projects Department Manuals are identified and will be applied based on the scope of the procedure. It must be noted that use of each and every procedure identified is not required for the complete project, rather, the use sha1l be determined by the applicable Project Engineer and the activity involved.

4.2 The engineering contractor(s) and acceptance inspection organization engaged in the activities of design verification, inspection and acceptance of project systems, components and structures shall provide an index or description of the implementing procedures to show compliance with quality programmatic requirements.

4.3 The CC shall prepare and provide applicable specific procedures where required within the Definitive Design documents. A17 other Procedures or Methods employed shall comply with the Codes and/or Standards identified within the Definitive Design documents. 
4.4 The OC reviews these indexes and implementing procedures for conformance and adequacy. These documents will provide the basis for technical reviews, survejllances, and audits of project activities to assure compliance to project requirements.

\subsection{REFERENCES}

The preparation of this QAPP is based upon the following references:

1. DOE Project Management System (DOE Order 4700.1 \& RLIP 4700.1A)

2. DOE Quality Assurance Order (DOE Order 5700.6C)

3. Quality Assurance Program Requirements for Nuclear Facilities (ASME NQA-1)

4. WHC Quality Assurance Manual (WHC-CM-4-2)

5. WHC Management Requirements \& Procedure Manual (WHC-CM-1-3)

6. WHC Safety Analys is Manual (WHC-CM-4-46)

7. WHC Functional Design Critieria (WHC-SD-FF-FDC-009)

8. Conceptual Design Report (WHC-SD-FF-CDR-006)

9. WHC Project Management Plan (WHC-SD-F031-PMP-001)

10. WHC Preliminary Safety Evaluation (WHC-SD-FF-PSE-002)

11. Hanford Site Hoisting and Rigging Manual (DOE RL 92-36) 
WHC-SD-F031-QAPP-001, Rev. 0

Page 10 of 16

\section{Attachment 1}

QA Requirements for WHC safety classes

\begin{tabular}{|c|c|c|}
\hline $\begin{array}{l}\text { WHC SAFETY } \\
\text { CLASSIFICATION* }\end{array}$ & DEFINITIONS* & $\begin{array}{l}\text { QUALITY ASSURANCE } \\
\text { REQUIREMENTS* }\end{array}$ \\
\hline safety class 1 & $\begin{array}{l}\text { Safety class } 1 \text { addresses } \\
\text { the offsite environment } \\
\text { and the health and safety } \\
\text { of the public. }\end{array}$ & $\begin{array}{l}\text { A comprehensive QA } \\
\text { program that meets all } \\
\text { applicable provisions of } \\
\text { the "Quality Assurance } \\
\text { Program Requirements for } \\
\text { Nuclear Facilities (ASME } \\
\text { NQA-1)" shall be used to } \\
\text { control all WHC safety } \\
\text { class } 1 \text { items. }\end{array}$ \\
\hline safety class 2 & $\begin{array}{l}\text { Safety class } 2 \text { addresses } \\
\text { onsite worker health and } \\
\text { safety and the onsite } \\
\text { environment. }\end{array}$ & $\begin{array}{l}\text { A graded approach shall } \\
\text { be used to apply } Q A \\
\text { program requirements. }\end{array}$ \\
\hline safety class 3 & $\begin{array}{l}\text { Safety class } 3 \text { addresses } \\
\text { the health and safety of } \\
\text { facility workers and } \\
\text { releases of radioactive or } \\
\text { toxic material to the } \\
\text { environment. }\end{array}$ & $\begin{array}{l}\text { As a minimum, } \\
\text { conventional industrial } \\
\text { standards (National } \\
\text { Electrical Code, National } \\
\text { Fire Protection } \\
\text { Association codes, } \\
\text { military standards, etc.) } \\
\text { shall be applied to WHC } \\
\text { safety class } 3 \text { items. } \\
\end{array}$ \\
\hline nonsafety class 4 & $\begin{array}{l}\text { Nonsafety class } 4 \text { has no } \\
\text { significant importance to } \\
\text { health, safety, or } \\
\text { environmental protection. }\end{array}$ & $\begin{array}{l}\text { No defined QA program } \\
\text { requirements apply to } \\
\text { nonsafety class } 4 \text { items. }\end{array}$ \\
\hline
\end{tabular}


Attachment 2

PROJECT CRITICAL CHARACTERISTICS

\begin{tabular}{|c|c|c|c|c|c|c|}
\hline \multirow{2}{*}{ ITEM } & \multirow{2}{*}{$\begin{array}{l}\text { DESCRIPTION OF ACTIVITY/SYSTEM } \\
\text { DA }\end{array}$} & \multirow{2}{*}{$\begin{array}{l}\text { SAFETY } \\
\text { CLASS }\end{array}$} & \multicolumn{3}{|c|}{$\begin{array}{c}\text { TYPE OF INSP } \\
\text { F=FUNCTIONAL } \\
\begin{array}{c}G \approx G E N E R A L \\
\text { D=DETAI }\end{array}\end{array}$} & \multirow[t]{2}{*}{$\begin{array}{lll} & \cdots & \\
\therefore & & \\
& & \\
& & \text { COMMENTS }\end{array}$} \\
\hline & & & $F$ & $G$ & ח & \\
\hline \multirow[t]{5}{*}{ I } & SITEWORK & -- & & & & \\
\hline & $\begin{array}{l}\text { Excavation/Removal of } \\
\text { Existing Heat Exchanger } \\
\text { Concrete }\end{array}$ & 4 & & $x$ & & \\
\hline & $\begin{array}{l}\text { Removal of Existing } \\
\text { Underground Utilities }\end{array}$ & 4 & $x$ & & & \\
\hline & - Backfill/Compaction & 4 & & $x$ & & \\
\hline & - Stormwater Drainage & 4 & & $x$ & & \\
\hline & & & & & & \\
\hline \multirow[t]{7}{*}{ II } & CONCRETE & -- & & & & \\
\hline & $\begin{array}{l}\text { - Sodium Storage Facility } \\
\text { (SSF) Footings/Foundation }\end{array}$ & 3 & & $x$ & & $\begin{array}{l}\text { Design for Seismic/Wind per } \\
\text { Safety Class } 2 \text { Criteria }\end{array}$ \\
\hline & $\begin{array}{l}\text { SSF Structural/Shielding } \\
\text { Walls }\end{array}$ & 3 & & $x$ & & $\begin{array}{l}\text { Design for Seismic/Wind per } \\
\text { Safety Class } 2 \text { Criteria }\end{array}$ \\
\hline & $\begin{array}{l}\text { SSF Mezzanine Shielding } \\
\text { Floor \& WaTls }\end{array}$ & 3 & & $x$ & & $\begin{array}{l}\text { Design for Seismic per Safety } \\
\text { Class } 2 \text { criteria }\end{array}$ \\
\hline & $\begin{array}{l}\text { Tanks - Foundation/Anchor } \\
\text { Bolts }\end{array}$ & 2 & & & $x$ & \\
\hline & - Roof Support Beam, Precast & 3 & & $x$ & & $\begin{array}{l}\text { Design for Seismic/Wind per } \\
\text { Safety Class 2 Criteria }\end{array}$ \\
\hline & - Roof Panels, Precast & 3 & & $x$ & & $\begin{array}{l}\text { Design for Seismic/Nind per } \\
\text { Safety Class } 2 \text { Criteria }\end{array}$ \\
\hline \multirow[t]{2}{*}{ III } & METALS & $\ldots$ & & & & \\
\hline & - Mezzanine Support Steel & 3 & & $x$ & & $\begin{array}{l}\text { Design for Seismic per Safety } \\
\text { Class } 2 \text { Criteria }\end{array}$ \\
\hline
\end{tabular}


WHC-SD-F031-QAPP-001, Rev. 0

Page 12 of 16

Attachment 2

PROJECT CRITICAL CHARACTERISTICS

\begin{tabular}{|c|c|c|c|c|c|c|}
\hline ITEM: & $\begin{array}{l}\text { DESCRIPTION OF ACTIVTTY/SYSTEM } \\
\text { OA }\end{array}$ & $\begin{array}{l}\text { SAFETY } \\
\text { CLASS } \%\end{array}$ & \multicolumn{3}{|c|}{ 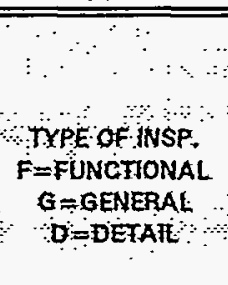 } & 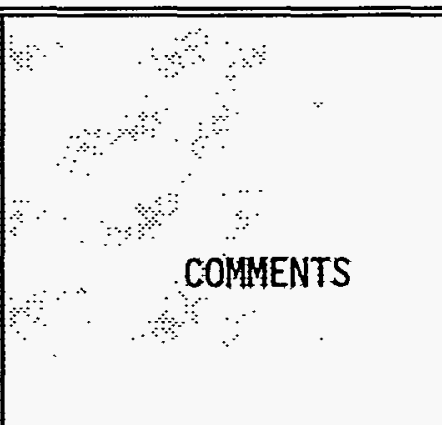 \\
\hline & - Mezzanine Tank Access Plates & 3 & & $x$ & & $\begin{array}{l}\text { Design for Seismic/wind per } \\
\text { Safety Class } 2 \text { Criteria }\end{array}$ \\
\hline & - Containment Sump (Drip Pan) & 3 & & $\mathrm{x}$ & & \\
\hline & - Sump Cover, Support Steel & 3 & & $\mathrm{x}$ & & \\
\hline & - Sump Cover, Perforated Areas & 3 & & $x$ & & \\
\hline & - Sump Cover, Steel Plate & 3 & & $x$ & & \\
\hline & - Piping Supports & 3 & & $x$ & & \\
\hline & - Interior Stairwells & 3 & & $x$ & & \\
\hline & - Ladder & 3 & & $x$ & & \\
\hline IV & INSULATION & - & & & & \\
\hline & - Tank(s) Insulation & 4 & & $x$ & & \\
\hline & - Sodium Piping Insulation & 4 & & $x$ & & \\
\hline $\mathbf{v}$ & Doors & - & & & & \\
\hline & - Access Doors & 3 & $\mathrm{x}$ & & & \\
\hline & . & & & & & \\
\hline VI & SPECIAL CONSTRUCTION & $\ldots$ & & & & \\
\hline & $\begin{array}{l}\text { - Pre-Engineered Structures } \\
\text { - Exterior Stairwells } \\
\end{array}$ & 3 & & $x$ & & \\
\hline & - Jib Hoist & 3 & & & $x$ & Load Test Required \\
\hline & & & & & & \\
\hline
\end{tabular}




\section{Attachment 2}

PROJECT CRITICAL CHARACTERISTICS

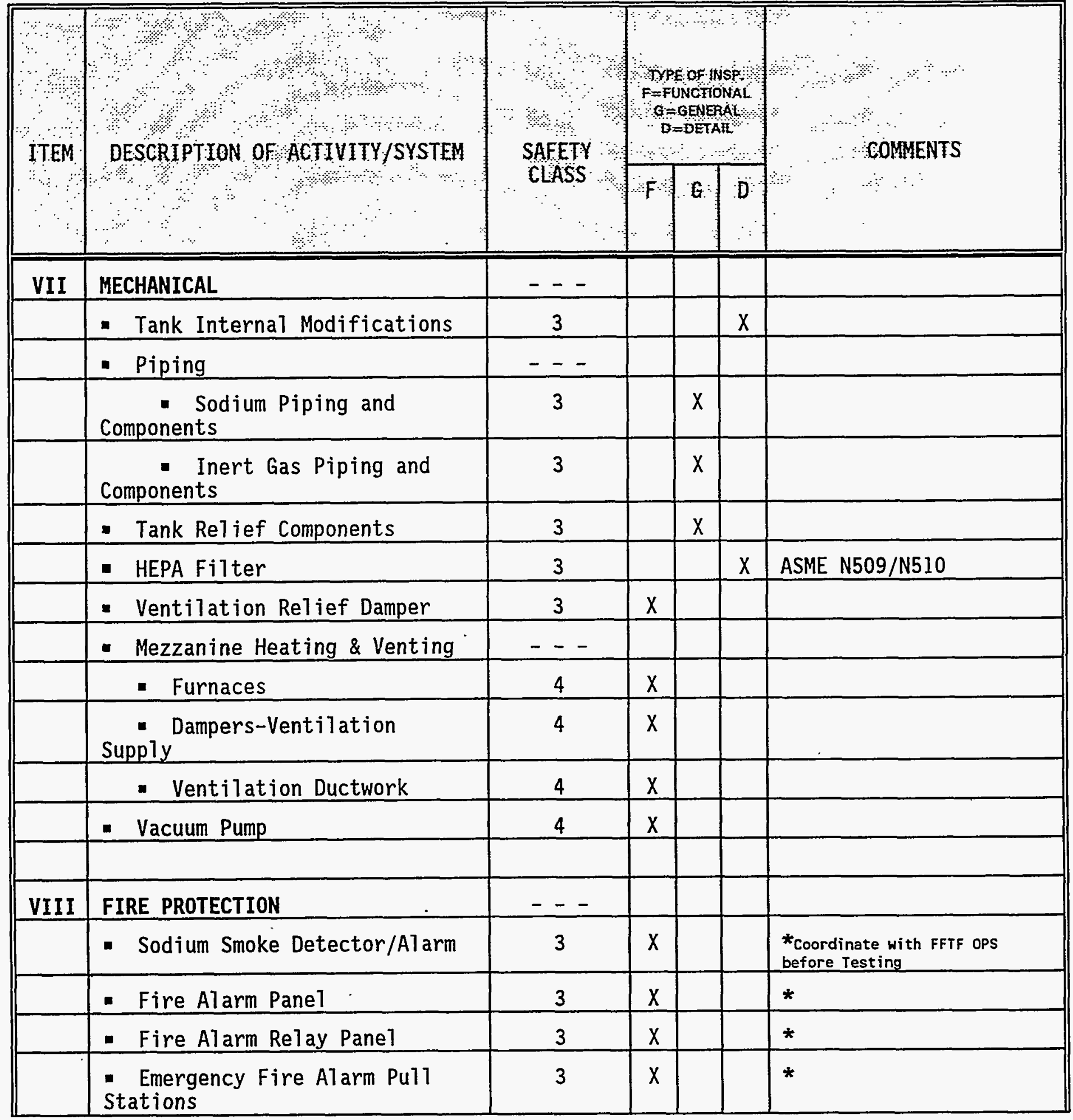


WHC-SD-F031-QAPP-001, Rev. 0

Page 14 of 16

Attachment 2

PROJECT CRITICAL CHARACTERISTICS

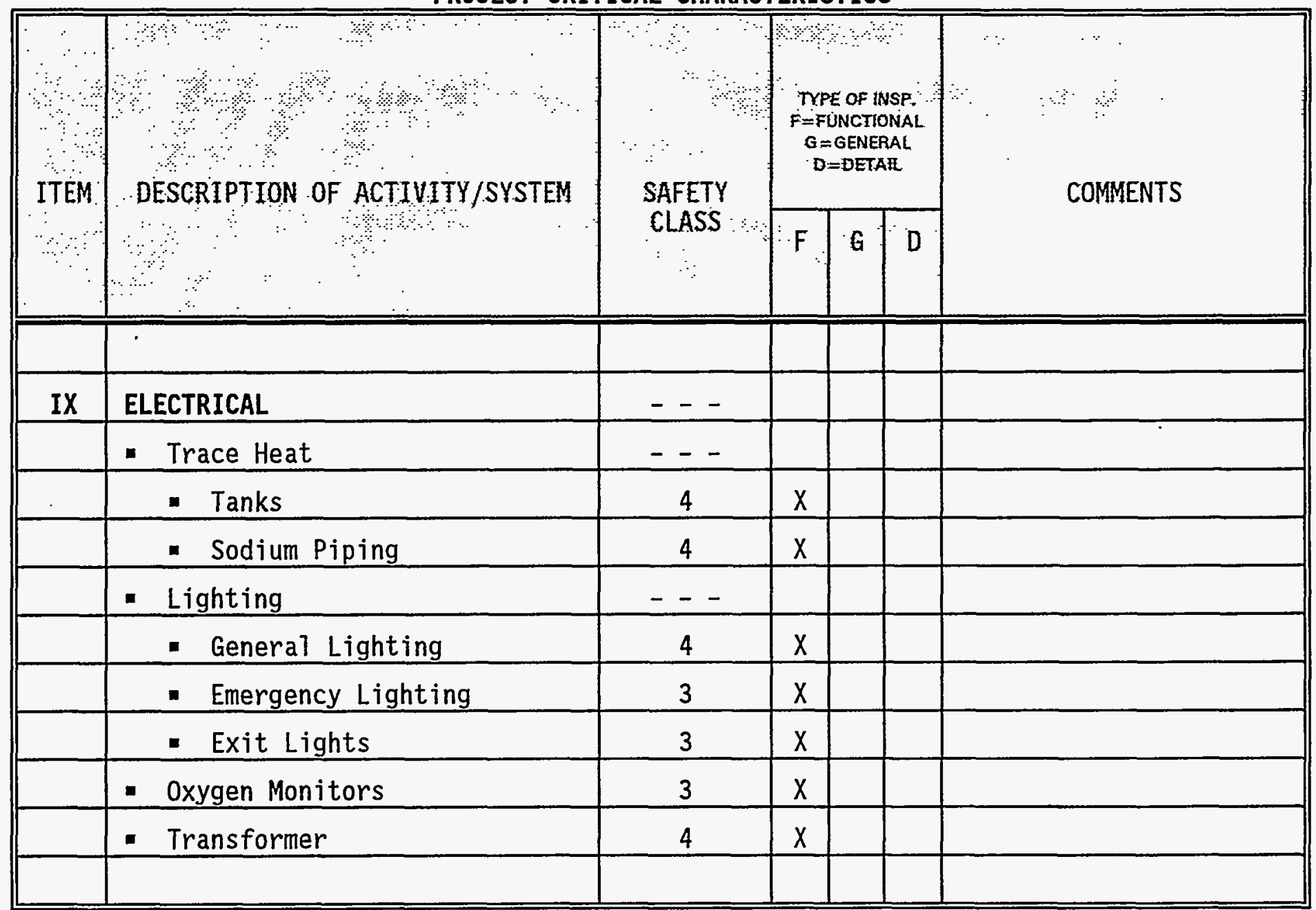

NOTE: All other items not identified above, 1isted in WHC-SD-FF-PSE-002, Appendix B (Preliminary Safety Equipment List), are to be classified as non-safety class 4 and do not have any $Q A$ Programmatic requirements applied to them. Acceptance Inspection activities involving non-safety class 4 systems, components, or structures shal1 be limited to overview to ensure installation per design. 
Attachment 3

\section{Description of Types of Inspection}

Types of Inspection. Due to the variety and types of contracts and subcontracts, and the degree of responsibility assigned to the operating contractors, the architect-engineer, the construction contractors, and the individual vendors; specific rules covering all phases of inspection cannot be prescribed. In general, inspection activities are divided into three types: functional, general, and detailed.

1. Functional Inspection. Performed to determine overall compliance with contract drawings and specifications. Functional Inspection may vary from inspection of minor items to extensive testing of operating equipment (which must be provided for in the contract). It may also serve in making initial determination of the adequacy of the design effort. The field element and the operating contractor participate in functional inspections from the viewpoints of owner and user.

2. General Inspection. The fundamental and comprehensive inspection to ascertain that workmanship and kind and quality of materials conform to the contract specifications.

3. Detailed Inspection. Includes, but is not limited to, verification of details, such as checking location and size of reinforcing bars, maintaining records of concrete batching plant operations, verifying the use of proper welding rods, checking riveting and welding, and performing other inspection for quality assurance purposes. It starts with initial construction operations and extends through a11 construction stages. 
Attachment 4

Quality Assurance Program Index

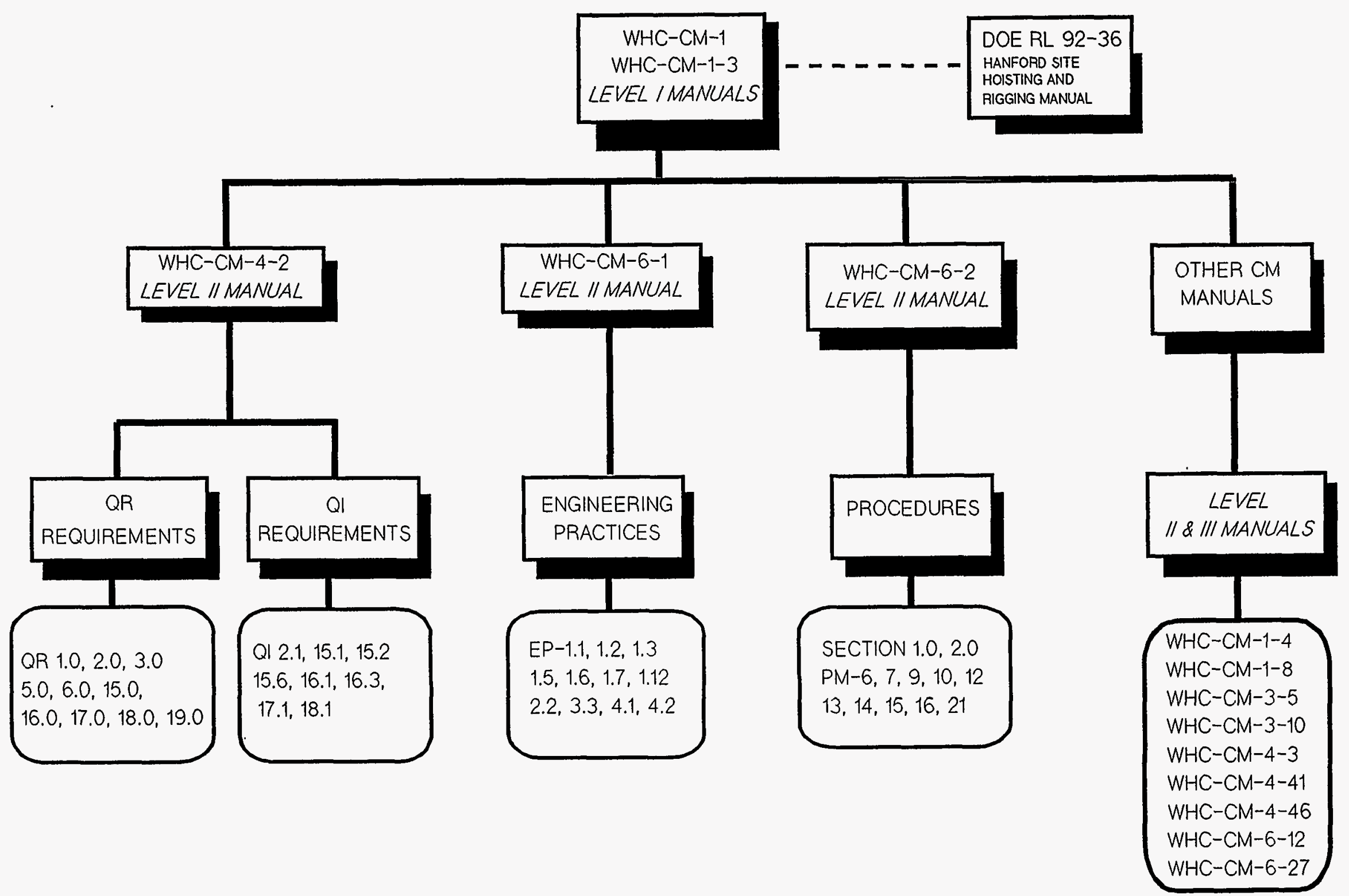

